\title{
Palynology as a Tool to Distinguish between Propolis and Geopropolis: Southern Brazilian Samples
}

\author{
Ortrud Monika Barth ${ }^{1,2 *}$, Alex da Silva de Freitas ${ }^{1,3}$ \\ ${ }^{1}$ Fundação Oswaldo Cruz, Instituto Oswaldo Cruz, Rio de Janeiro, Brazil \\ ${ }^{2}$ Universidade Federal do Rio de Janeiro, Laboratório de Palinologia, Departamento de Geologia, CCMN, \\ Rio de Janeiro, Brazil \\ ${ }^{3}$ Universidade Federal Fluminense, Instituto de Geociências, Departamento de Geologia, Niterói, Brazil \\ Email: *monikabarth@gmail.com.br, alexsilfre@gmail.com
}

Received 28 November 2015; accepted 12 December 2015; published 16 December 2015

Copyright (C) 2015 by authors and OALib.

This work is licensed under the Creative Commons Attribution International License (CC BY).

http://creativecommons.org/licenses/by/4.0/

(c) (i) Open Access

\section{Abstract}

Propolis is a product elaborated by honey bees (Apis) and comprises plant resins, bee wax, glandular secretions of the worker bees and pollen grains. Geopropolis is a product elaborated by stingless bees and comprises similar compounds of honey bees and soil, mud, clay, earth or sand. The present study intends to distinguish between propolis and geopropolis using pollen analysis. A total of 12 samples were obtained in the Southern Brazilian macro-region and processed by standard melissopalynological methodology. All structural components recovered after alcoholic extraction and before acetolysis treatment were evaluated. Four of the eight samples collected in the State of Paraná were prepared by Apis and showed a strong contribution of Asteraceae and Eucalyptus pollen grains. On the other hand, the two geopropolis samples of Tetragonisca angustula contained mainly Cecropia pollen grains, while the samples of Melipona quadrifasciata and Melipona mondury showed a predominance of Melastomataceae pollen grains. The four propolis samples obtained in the Santa Catarina and Rio Grande do Sul States were characterized by a predominant pollen contribution of Asteraceae and Eucalyptus. Additional structured elements in propolis samples comprised frequently plant trichomes and tissue fragments. On the contrary, the geopropolis samples showed high values of spores of fungi, amorphous organic matter, sand or clay and sometimes remainder of resin. In conclusion, the pollen grain spectra do not distinguish between propolis of Apis and geopropolis of stingless bees, but the accessory elements are conclusive.

\section{Keywords}

Propolis, Geopropolis, Palynology, Pollen Analysis, Southern Brazil

${ }^{*}$ Corresponding author. 


\section{Introduction}

Honey bees (Apis sp.) were introduced in Southern Brazil by European immigrants, mainly Jesuit priests, in the XVII century, into the region of Missões, banks of the River Uruguai [1], but in sequence abandoned. The priest Antônio Carneiro in the year of 1839 reintroduced bees again. He brought with them a long tradition in apicultural activities. Their knowledge comprised mainly honey and pollen production, as well as crop pollination and medicinal use of bee products. Attending very different climatic conditions, honey bees and beekeepers learned to use a new vegetation to survive and prospered until 1956.

At this time, an African bee species (Apis mellifera adansonii Latreille, 1804) was accidentally introduced in the Brazilian state of São Paulo, Ribeirão Preto locality. The hybrid bees originated turned strongly aggressive and dominant and spread from this county into Southern Brazil too [2]. Beekeepers learned to handle the resulting populations, and got high production of honeys. More recently, dry bee pollen and propolis became of great commercial value.

Propolis is a product elaborated by honey bees starting to collect plant resins into its basquetes. This resin was obtained from some damaged tree stems or branches [3]. In a special case of green propolis, the bees chew leave buds to open the plant resin channels, introducing plant tissue fragments accidentally into its propolis [4]. Mixing the resin with bee wax, glandular secretion of the worker bees is added, and the result is a material used to seal holes and cracks inside the honeycomb and to isolate foreign incomes. By making artificial holes between the honeycomb walls and grids, beekeepers collect a great amount of propolis of high commercial value [5].

Physico-chemical analyses of propolis revealed the presence of several substances such as flavonoids, terpenoids and amino acids, antioxidant activity and more [6]-[8]. The variable concentrations of these compounds are depending upon the bee population and the environmental conditions [9]. Alcoholic and aqueous extracts of propolis are used in pharmacological products elaboration [7] [10].

Structural elements in propolis samples were isolated as a rule by ethanol extraction. After elimination of resins and bee-wax, pollen grains (more or less $5 \%$ of the sediment amount), hyphae and spores of fungi, yeast, bacteria, plant tissue fragments and trichomes and organic clusters can be recovered [11] [12]. All these elements together translate a high image of environmental condition and vegetation around the apiaries. In consequence a better or worthier quality of propolis can be obtained by the beekeepers.

Numerous species of native stingless bees, the Meliponini, are important pollinators of the original vegetation. In the same way as honeybees do, these bees elaborate a compound similar of propolis, named geopropolis. This term was formerly purposed by Nogueira-Neto [13]. It means a product made by the Meliponini using plant resins, bee-wax, bee glandular secretion and soil mud, clay, earth or sand. It does not contain plant tissue and trichomes. The honey of Meliponini is harvested inside the nests in little pots [13]. These pots are made of a mixture of resin and bee-wax only, named "cerume/cerúmen” in Brazil, and are not as resistant as geopropolis.

Nests of Meliponini occur originally inside tree holes, inside walls and between stones [14], so that the quantity of geopropolis produced is small and of low commercial significance at the moment. These bees are actually kept by beekeepers and maintained inside little boxes and, without any danger, next to human homes. Recently, the maintenance and development of social species of Meliponini was supported by Brazilian government entities for honey production by SEBRAE (Serviço Brasileiro de Apoio às Micro e Pequenas Empresas).

In attending scientific and commercial interests, analysis of pollen grains and other structured elements that occur inside propolis and geopropolis is useful. It is possible to identify the phytogeographical region [15] [16] where these products are elaborated. Different regions in Brazil produce propolis of several qualities, recognized when fresh by its color as brown, dark, red, grey or green (Figure 1), when not fresh, after some months they turn dark-brown. The most appreciated are the green and red propolis, the first being an important product of export [17]. Regarding the botanical and physicochemical properties of both propolis and geopropolis, the knowledge of its composition and geographical origin may exclude falsifications.

Physico-chemical analyses revealed geopropolis has a similar composition as propolis. The main difference is a variable concentration of each significant component. Phenolic acids and flavonoids mainly present lower concentration in geopropolis [18] than in propolis [19]. Pollen analysis of propolis and geopropolis reveals the 
occurrence of bee plants far or next to the beehives, bee nests and apiaries. On the one hand, it consists of nectariferous and poliniferous plant species, on the other hand of resin producing plants. This together makes the land useful or not for apicultural activities using honeybees and/or stingless bees.

The Brazilian flora belongs to five macro-regions (North, Northeast, Midwest, Southeast and South). The Southern region (Figure 2) comprises the ombrophilous forest, a field vegetation ("Campos Sulinos"), a "Restinga" formation [20] and patches of a "Cerrado" vegetation in the State of Paraná [21]. The transition of the tropical to a subtropical environment occurs in the state of Paraná, with a great variety of plant associations. Araceae, Arecaceae, Asteraceae, Euphorbiaceae, Lauraceae, Melastomataceae, Myrsinacea and Myrtacea were the most representative families (Troppmair, 1990). The "Cerrado" areas showed different plant taxa [22].

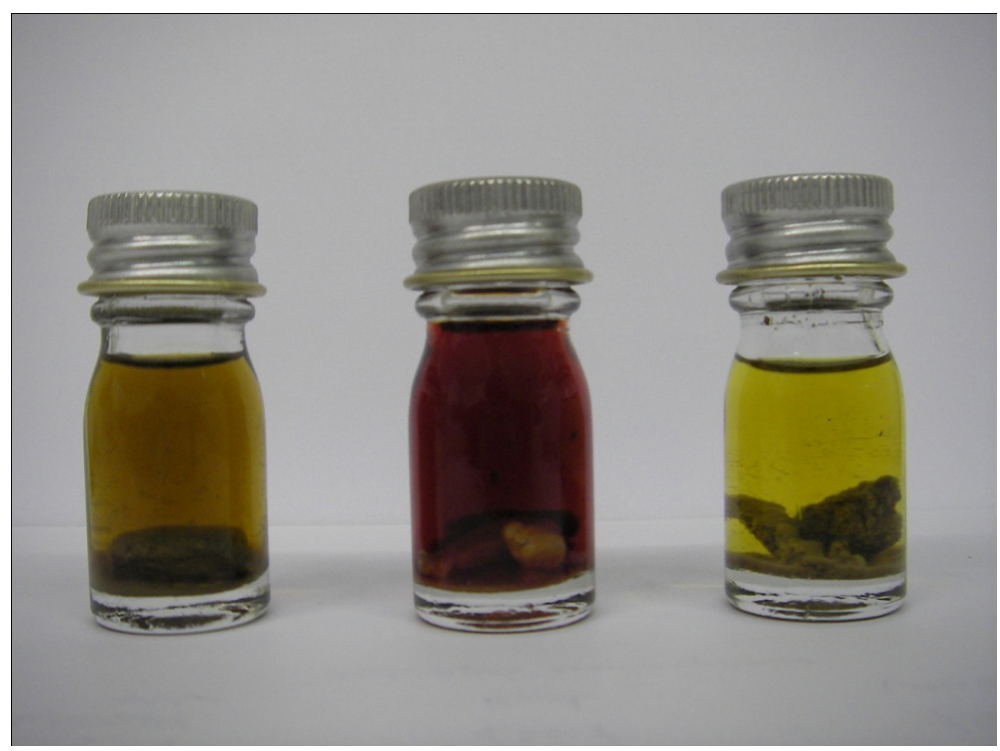

Figure 1. Brown, red and green propolis alcoholic extracts showing the respective colorations.

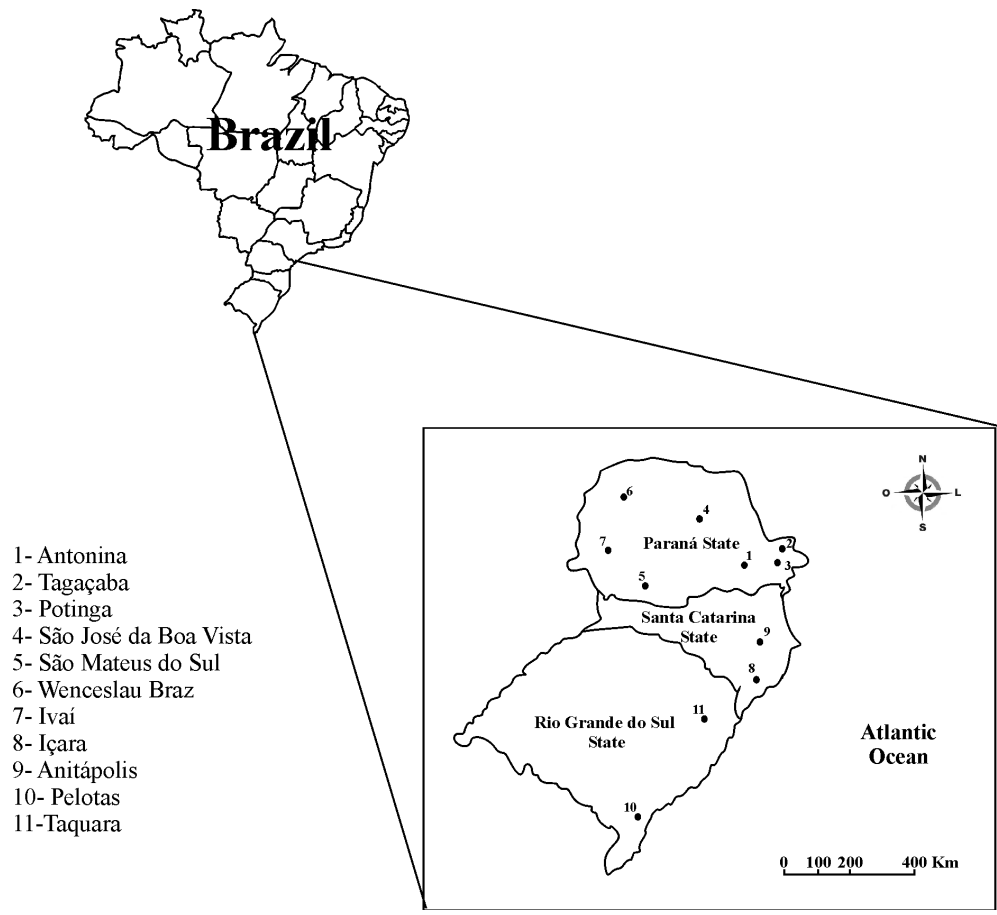

Figure 2. South Brazilian macro-region where samples were obtained on. 
The ombrophilous and the Araucaria angustifolia forests characterize the vegetation of Santa Catarina State [23]. Species richness occurs in Asteraceae, Cyperaceae, Fabaceae, Lauraceae, Melastomataceae, Myrtaceae, Piperaceae, Poaceae, Orchidaceae, Rubiaceae and Solanaceae families [24]. The Rio Grande do Sul State vegetation comprises savanna areas [21]. The ombrophilous forest in this state is represented mainly by the Euphorbiaceae, Fabaceae, Lauraceae and Myrtaceae families [25]. The "Restinga" formation is characterized by Asteraceae, Cyperaceae, Fabaceae, Myrtaceae and Poaceae [26].

The present study intends to distinguish between propolis and geopropolis by using a palynological analysis. It also intends to recognize the local or regional and melissopalynological vegetation around the beehives and nests.

\section{Material and Methods}

Samples were collected in the Southern Brazilian region. Propolis samples became two from each of the States of Rio Grande do Sul and Santa Catarina and four from Paraná. Four geopropolis samples were from Paraná State. The 12 samples proceed from beekeepers and its apiaries (Table 1).

Table 1. Localities, bee species and palynological evaluation of propolis and geopropolis samples of Southern Brazil. AP = accessory pollen grains $(15 \%-45 \%)$, IP $=$ important isolated pollen grains $(3 \%-15 \%)$, PP = predominant pollen grains $(>45 \%)$.

\begin{tabular}{|c|c|c|c|}
\hline Brazilian state & $\begin{array}{l}\text { Municipalities/GPS } \\
\text { coordinates }\end{array}$ & Bee species & Pollen grain frequencies \\
\hline \multirow{8}{*}{ Paraná (PR) } & $\begin{array}{l}\text { Antonina } \\
25^{\circ} 10^{\prime} 05.2^{\prime \prime} \mathrm{S} \\
48^{\circ} 17^{\prime} 58.9^{\prime \prime} \mathrm{W}\end{array}$ & Tetragonisca angustula & $\begin{array}{l}\text { AP: Cecropia (26.0\%), unidentified }(17.0 \%) \text {; } \\
\text { IP: Alchornea }(13.2 \%) \text {, Sapium }(11.9 \%) \text {, } \\
\text { Loranthaceae }(3.8 \%)\end{array}$ \\
\hline & Tagaçaba & Tetragonisca angustula & $\begin{array}{l}\text { AP: Cecropia (32.0\%), Arecaceae (25.8\%); } \\
\text { IP: Melastomataceae (3.5\%), Sapium (11.9\%) }\end{array}$ \\
\hline & $\begin{array}{l}25^{\circ} 17^{\prime} 59.8^{\prime \prime S} \\
48^{\circ} 18^{\prime} 41.8^{\prime \prime} \mathrm{W}\end{array}$ & Melipona quadrifasciata & $\begin{array}{l}\text { PP: Melastomataceae (75.5\%); } \\
\text { IP: Matayba (6.8\%); Myrcia (4.0\%); } \\
\text { Mimosa scabrella (3.7\%); }\end{array}$ \\
\hline & $\begin{array}{l}\text { Potinga } \\
25^{\circ} 45^{\prime} 24.9^{\prime \prime} \mathrm{S} \\
50^{\circ} 38^{\prime} 34.2^{\prime \prime} \mathrm{W}\end{array}$ & Melipona mondury & $\begin{array}{l}\text { PP: Melastomataceae (50.6\%); } \\
\text { IP: Matayba (13.2\%), Alchornea (9.6\%), } \\
\text { Myrcia (6.0\%), Asteraceae (4.8\%) }\end{array}$ \\
\hline & $\begin{array}{l}\text { São José da Boa Vista } \\
23^{\circ} 54^{\prime} 47.7 " \mathrm{~S} \\
49^{\circ} 38^{\prime} 37.1^{\prime \prime W}\end{array}$ & Apis mellifera & $\begin{array}{l}\text { AP: Eucalyptus (38.4\%), Asteraceae }(17.9 \%) \text {; } \\
\text { IP: Tapirira (8.7\%), Arecaceae }(9.5 \%), \\
\text { Psychotria }(10.2 \%) \text {, Paullinia }(6.4 \%) \text {, Solanum }(5.7 \%)\end{array}$ \\
\hline & $\begin{array}{l}\text { São Mateus do Sul } \\
25^{\circ} 52^{\prime} 40.0^{\prime \prime S} \\
50^{\circ} 22^{\prime} 34.0^{\prime \prime} \mathrm{W}\end{array}$ & Apis mellifera & $\begin{array}{l}\text { AP: Asteraceae (33.5\%), Eucalyptus (21.7\%); } \\
\text { IP: Tapirira (11.7\%), Arecaceae (13.4\%) }\end{array}$ \\
\hline & $\begin{array}{l}\text { Wenceslau Brás } \\
23^{\circ} 52^{\prime} 18.7^{\prime \prime S} \\
49^{\circ} 47^{\prime} 32.9^{\prime \prime} \mathrm{W}\end{array}$ & Apis mellifera & $\begin{array}{l}\text { PP: Asteraceae (46.7\%), Eucalyptus (32.1\%); } \\
\text { IP: Arecaceae (10.2\%), Solanaceae }(7.3 \%)\end{array}$ \\
\hline & $\begin{array}{l}\text { Ivaí } \\
25^{\circ} 00^{\prime} 43.5^{\prime \prime} \mathrm{S} \\
50^{\circ} 50^{\prime} 44.0^{\prime \prime} \mathrm{W}\end{array}$ & Apis mellifera & $\begin{array}{l}\text { PP: Asteraceae (71.8\%); } \\
\text { IP: Arecaceae (12.8\%), Eucalyptus (13.5\%) }\end{array}$ \\
\hline \multirow{2}{*}{$\begin{array}{l}\text { Santa Catarina } \\
\text { (SC) }\end{array}$} & $\begin{array}{l}\text { Içara } \\
28^{\circ} 44^{\prime} 22.7^{\prime \prime S} \\
49^{\circ} 19^{\prime} 27.0^{\prime \prime} \mathrm{W}\end{array}$ & Apis mellifera & $\begin{array}{l}\text { AP: Eucalyptus (42.1\%), Asteraceae (22.5\%); } \\
\text { IP: Fabaceae (10.3\%), Myrcia (10.7\%) }\end{array}$ \\
\hline & $\begin{array}{l}\text { Anitápolis } \\
27^{\circ} 54^{\prime} 01.7^{\prime \prime} \mathrm{S} \\
49^{\circ} 08^{\prime} 04.5^{\prime \prime} \mathrm{W}\end{array}$ & Apis mellifera & $\begin{array}{l}\text { AP: Eucalyptus (34.0\%), Asteraceae (18.3\%); } \\
\text { IP: Arecaceae (10.1\%), Cyperaceae (5.3\%), } \\
\text { Euphorbiaceae (3.4\%), Melastomataceae (3.1\%), } \\
\text { Mimosa verrucosa (7.2\%), Solanum }(3.4 \%)\end{array}$ \\
\hline \multirow{2}{*}{$\begin{array}{l}\text { Rio Grande do Sul } \\
\text { (RGS) }\end{array}$} & $\begin{array}{l}\text { Pelotas } \\
31^{\circ} 44^{\prime} 56.3^{\prime \prime} \mathrm{S} \\
52^{\circ} 13^{\prime} 49.3^{\prime \prime} \mathrm{W}\end{array}$ & Apis mellifera & $\begin{array}{l}\text { AP: Asteraceae (29.5\%), Eucalyptus (27.2\%); } \\
\text { IP: Anacardiaceae (7.8\%), Mimosa verrucosa (10.9\%), } \\
\text { Theaceae (3.5\%) }\end{array}$ \\
\hline & $\begin{array}{l}\text { Taquara } \\
29^{\circ} 40^{\prime} 59.7^{\prime \prime S} \\
50^{\circ} 46^{\prime} 28.2^{\prime \prime} \mathrm{W}\end{array}$ & Apis mellifera & $\begin{array}{l}\text { PP: Eucalyptus (50.3\%); } \\
\text { AP: Asteraceae }(15.9 \%) \text {, Solanum }(15.6 \%) \text {, } \\
\text { IP: Psychotria }(4.3 \%)\end{array}$ \\
\hline
\end{tabular}


Extraction of pollen grains and other structured particles follows the technique described in [11] [12] [27]. Shortly, after alcoholic extraction of $0.5 \mathrm{~g}$ of any sample, the sediment was treated with $10 \% \mathrm{KOH}$, washed and slides to detect trichomes and plant tissue were prepared using glycerin-jelly. The remaining sediment was dehydrated in concentrated acetic acid, washed, submitted to acetolysis, washed again, and left for more than 30 min in a water-glycerin 1:1 mixture. Slides were prepared with glycerin-jelly also and sealed with paraffin. More than 300 pollen grains were considered under 400x magnification.

\section{Results}

\subsection{Propolis Samples}

Considering the three States of the Southern Brazilian region, the eight propolis samples contained mainly predominant or accessory pollen grains of Eucalyptus (13.5\% - 50.3\%) and of several species of Asteraceae (15.9\% - 71.8\%) (Table 1 and Table 2). Forty additional taxa showed lower participation, as Arecaceae in five samples, Solanum in three samples, Tapirira (Anacardiaceae), Mimosa verrucosa pollen type and Psychotria (Rubiaceae) in two samples, and Anacardiaceae, Cyperaceae, Euphorbiaceae, Fabaceae, Melastomataceae, Myrcia (Myrtaceae), Paullinia (Sapindaceae), Solanaceae and Theaceae in one sample only.

Trichomes and plant tissue fragments occurred in all propolis samples and have to be detected before acetolysis was applied. Some samples presented few amorphous organic materials.

\subsection{Geopropolis Samples}

The four geopropolis samples analyzed proceeded from the State of Paraná. Two were collected by Tetragonisca angustula ("jataí") and two by Melipona quadrifasciata ("mandaçaia”) and M. mondury ("uruçu-amarela”) bees (Table 1 to Table 2). They presented rarely or no Eucalyptus pollen grains.

Table 2. State of Paraná. Occurrence of the main botanical taxa identified in propolis and geopropolis samples.

\begin{tabular}{|c|c|c|c|c|c|}
\hline \multicolumn{6}{|c|}{ Samples of the State of Paraná } \\
\hline \multicolumn{3}{|c|}{ Propolis (Apis) } & \multicolumn{3}{|c|}{ Geopropolis (Meliponini) } \\
\hline Taxon & Number of samples & Percentages (\%) & Taxon & Number of samples & Percentages (\%) \\
\hline Asteraceae & $4 / 4$ & $17.9-71.8$ & Asteraceae & $1 / 4$ & 4.8 \\
\hline Eucalyptus & $4 / 4$ & $13.5-38.4$ & - & - & - \\
\hline Arecaceae & $3 / 4$ & $9.5-13.4$ & Arecaceae & $1 / 4$ & 25.8 \\
\hline Tapirira & $2 / 4$ & $8.7-11.7$ & - & - & - \\
\hline Psychotria & $1 / 4$ & 10.2 & - & - & - \\
\hline Solanaceae & $1 / 4$ & 7.3 & - & - & - \\
\hline Paullinia & $1 / 4$ & 6.4 & - & - & - \\
\hline Solanum & $1 / 4$ & 5.7 & - & - & - \\
\hline- & - & - & Melastomataceae & $3 / 4$ & $3.5-75.5$ \\
\hline- & - & - & Cecropia & $2 / 4$ & $26.0-32.0$ \\
\hline- & - & - & Alchornea & $2 / 4$ & $9.6-13.2$ \\
\hline- & - & - & Matahyba & $2 / 4$ & $6.8-13.2$ \\
\hline- & - & - & Sapium & $2 / 4$ & 11.9 \\
\hline- & - & - & Myrcia & $2 / 4$ & $4.0-6.0$ \\
\hline- & - & - & Loranthaceae & $1 / 4$ & 3.8 \\
\hline- & - & - & Mimosa scabrella & $1 / 4$ & 3.7 \\
\hline
\end{tabular}


Predominant taxon was a Melastomataceae pollen type (Tibouchina-like) (50.6\% - 75.5\%) in the two samples produced by Melipona. Nevertheless, T. angustula samples presented predominant and accessory pollen grains of Cecropia (32.0 and 26.0\%), and Arecaceae (25.8\%). Additional taxa of lower participation in geopropolis samples of $T$. angustula belong to Alchornea, Sapium and Loranthaceae; the lowest frequency was of Melastomataceae in one sample of Tragaçaba. The Melipona geopropolis samples showed no accessory pollen beside several taxa of low participation (Table 1).

All geopropolis samples presented hyphae and spores of fungi and sand, clay, mud or similar inorganic compounds, amorphous organic material (Figure 3) and frequently patches of resin resisting acetolysis (Table 3).
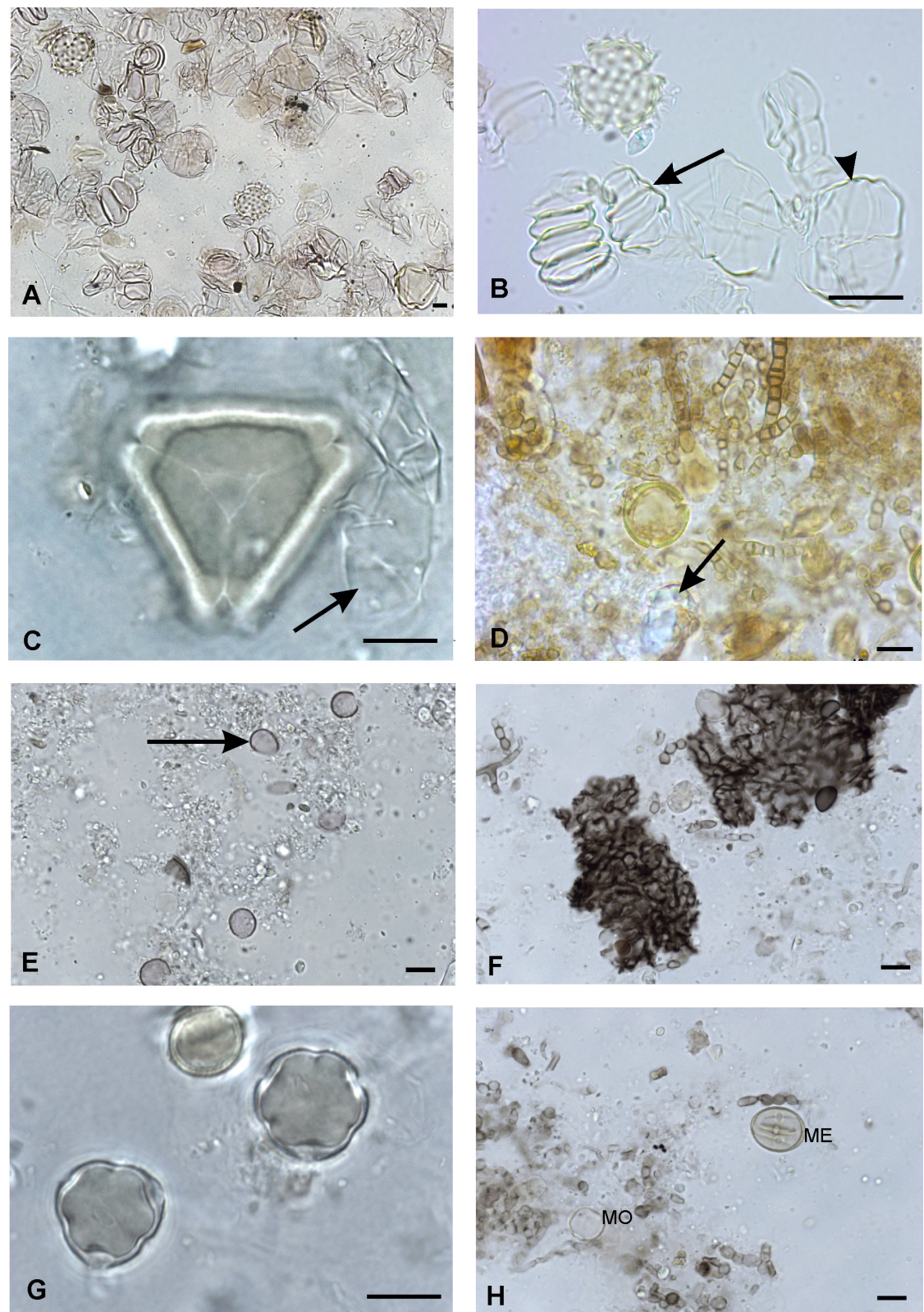

Figure 3. Propolis samples: A. glandular trichomes and pollen grains; B. pollen grain of Asteraceae and trichomes (trichome head = arrow head, trichome stalk = arrow); C. pollen grain of Eucalyptus and trichome (arrow). Geopropolis samples; D. pollen grain of Alchornea (Euphorbiaceae), spores of fungi and a translucent mineral particle (arrow); E. pollen grain of Piper (arrow) and sand; F. plant tissue, hyphae and spores of fungi; G. pollen grains of Melastomataceae; $\mathrm{H}$. shows pollen grain of Meliaceae (ME) and Moraceae (MO) and fungi spores. Bar $=10 \mu \mathrm{m}$. 
Table 3. Localities, bee species and evaluation of additional structured elements except pollen grains. $(-)=$ without, $(+)=$ few, $(++)=$ medium,$(+++)=$ frequent, $(++++)=$ very frequent structured elements.

\begin{tabular}{|c|c|c|c|c|c|c|}
\hline $\begin{array}{c}\text { Brazilian } \\
\text { states }\end{array}$ & Municipalities & Bee species & Trichomes & $\begin{array}{l}\text { Hyphae and } \\
\text { spores of fungi }\end{array}$ & $\begin{array}{c}\text { Sand/Clay/ } \\
\text { mud fragments }\end{array}$ & $\begin{array}{c}\text { Amorphous } \\
\text { organic material }\end{array}$ \\
\hline \multirow{8}{*}{$\begin{array}{c}\text { Paraná } \\
\text { (PR) }\end{array}$} & Antonina & Tetragonisca angustula & - & +++ & + & + \\
\hline & Tragaçaba & Tetragonisca angustula & - & + & + & ++++ \\
\hline & Tragaçaba, & Melipona quadrifasciata & - & + & + & ++++ \\
\hline & Potinga & Melipona mondury & - & + & +++ & +++ \\
\hline & São José da Boa Vista & Apis mellifera & ++++ & - & - & - \\
\hline & São Mateus do Sul & Apis mellifera & ++++ & - & - & - \\
\hline & Wenceslau Brás & Apis mellifera & ++++ & - & - & - \\
\hline & Ivaí & Apis mellifera & ++++ & - & - & - \\
\hline \multirow{2}{*}{$\begin{array}{c}\text { Santa } \\
\text { Catarina (SC) }\end{array}$} & Içara & Apis mellifera & ++ & - & - & ++ \\
\hline & Anitapolis & Apis mellifera & +++ & - & - & - \\
\hline \multirow{2}{*}{$\begin{array}{l}\text { Rio Grande } \\
\text { do Sul (RGS) }\end{array}$} & Pelotas & Apis mellifera & ++++ & - & - & + \\
\hline & Taquara & Apis mellifera & ++ & - & - & ++ \\
\hline
\end{tabular}

\section{Discussion}

A total of 22 taxa could be identified in the propolis and geopropolis samples (Table 1). Only four taxa were found in both, the pollen types of Arecaceae, Asteraceae, Melastomataceae and Myrcia. These are strong representatives of the ombrophilous forest vegetation.

\subsection{Propolis Samples}

The eight samples of propolis collected in the Southern Brazilian macro-region presented pollen grains belonging to 16 taxa of three or more percent frequency (Table 1). Eucalyptus and several species of Asteraceae, the most frequent in all samples, indicate areas around the beehives of vegetation composed of trees, shrubs and lowland plant taxa. The four Paraná samples showed a similar pollen grain assemblage, Asteraceae-Eucalyptus - Arecaceae. This last taxon was not detected in the Santa Catarina and Rio Grande do Sul samples.

Palynological analysis of propolis samples of several Brazilian regions Brazil emphasized that predominant plant taxa in the Southern and Southeast regions comprised mainly Eucalyptus species, followed by Asteraceae [15]. Mimosa pollen grains were rarely found in propolis samples of the Southern region. On the other hand, in the Northeast Brazilian region the pollen types of Mimosa, Borreria and Acacia were predominant [15] [28]. This shows a strong macro-regional variation.

By analogy to propolis samples from Baccharis dracunculifolia analysed by [4], the richness of trichomes in the studied samples may be attributed to species of the Asteraceae family. Trichomes were detected only inside the propolis samples.

\subsection{Geopropolis Samples}

The four samples of geopropolis showed pollen grains belonging to 10 taxa of three or more percent frequency (Table 1). The most frequent taxa of Melastomataceae, Cecropia and Arecaceae indicate areas presenting native forest border vegetation around the beehives. The vigorous Melipona bees certainly visited a high tree canopy to obtain pollen grains of Melastomataceae by vibration of the poricide anthers. Ramalho [29] highlights the importance of the stingless bees in foraging trees in a canopy tropical forest. Pollen grains of herbs were rarely detected in this and in the present study, remaining below 3\% in the samples.

Nascimento et al. [30] observed high frequency of Tibouchina, Cecropia and Syagrus pollen grain types in honey samples obtained in the Paraná state. This fact confirms the data of geopropolis samples here presented 
indicating that, in addition to food resources for the colony maintenance, there is a strong interest of bees as visitors and pollinators of these plants.

The Eucalyptus pollen type was frequently observed in geopropolis samples of Southeast Brazil [12] [31], but rarely in the Southern macro-region as in the present study and in [16]. However, Nascimento et al. [30] highlight the presence of this pollen type in honey samples of M. quadrifasciata in the Paraná State.

Cecropia pollen type was found as secondary pollen in the honey samples from M. quadrifasciata in the Paraná State [30]. In the present study this pollen type was found in the geopropolis samples from $T$. angustula. This genus is characterized as pioneer trees [32] of anemophilous pollen transport.

\subsection{Propolis $\mathrm{x}$ Geopropolis Samples}

Pollen grains of the Asteraceae family firstly and of Eucalyptus species secondly characterized the propolis samples studies in the Southern Brazilian region. This fact is strongly different from the singles bee geopropolis samples, which showed mainly Melastomataceae and Cecropia pollen grains. Tibouchina and Miconia (Melasto- mataceae) and Cecropia (Cecropiaceae) pollen types were observed recently in honey samples of Melipona quadrifasciata and M. mondury [30]. This stingless bee behavior indicates that these plants were used as a good food resource.

Eucalyptus pollen grains may indicate human activities next to the apiaries. This genus is extensively cultivated in the Southeast and Southern Brazil. Pollen grains have been found as dominant and secondary pollen in propolis samples of the three states in Southern Brazil [15]. Pollen grains of introduced crops as orange, coffee, apple and tobacco were absent in geopropolis samples.

Amorphous organic material, soil or sand and fungi in the geopropolis samples studied of both, Tetragonisca and Melipona bees, were not bee species specific.

Patches of plant resins sometimes resist acetolysis procedure and were detected in the slides of Paraná state geopropolis. [3] emphasized resins of "aroeira" trees (Schinus terebinthifolius and/or related species) collected by Tetragonisca angustula. They mentioned the importance of resin obtained from Araucaria angustifolia also, which pollen grains were at the moment not detected in the Southern State samples.

Plant tissue fragments and trichomes were introduced into propolis when the bees (Apis) cut the top of plant buds, using its mandibles, in order to open resin channels [33] however stingless bees do not make this [12]. In this respect, the best technique to distinguish between propolis and geopropolis is the presence of plant tissue and trichomes inside propolis and sand or clay inside geopropolis samples. Apis species never collect inorganic material.

Depending upon locality, climatic condition and season, the vegetation investigated by Apis around the apiaries is not the same as the investigated by stingless bees, nevertheless some plant taxa may occur in common. Propolis and geopropolis are always bee species dependant.

\section{Conclusion}

In conclusion, the pollen grain spectra do not distinguish exactly between propolis of Apis and geopropolis of stingless bees, but the accessory elements are conclusive, mainly trichomes and mineral elements.

\section{Acknowledgements}

Financial support: Conselho Nacional de Desenvolvimento Científico e Tecnológico (CNPq) to the first author (Fellowship process number 304067/2013-0).

\section{References}

[1] Wiese, H. (1984) Nova Apicultura. 5th Edition, Livraria e Editora Agropecuária Ltda., Porto Alegre, 485 p.

[2] Oliveira, M.L. and Cunha, J.K. (2005) Abelhas africanizadas Apis mellifera scutellata Lepeletier, 1836 (Hymenoptera: Apidae: Apinae) exploram recursos na floresta amazônica? Acta Amazônica, 35, 389-394. http://dx.doi.org/10.1590/S0044-59672005000300013

[3] Sawaya, A.C.H.F., Cunha, I.B.S., Marcucci, M.C., Aidar, D.S., Silva, E.C.A., Carvalho C.A.L. and Eberlin, M.N. (2007) Electrospray Ionization Mass Spectrometry Fingerprinting of Propolis of Native Brazilian Stingless Bees. Apidologie, 38, 93-103. http://dx.doi.org/10.1051/apido:2006058 
[4] Bastos, E.M.A.F., Santana, R.A., Calaça-Costa, A.G.F. and Thiago, P.S. (2011) Interaction between Apis mellifera L. and Baccharis dracunculifolia DC, that Favours Green Propolis Production in Minas Gerais. Brazilian Journal of Biology, 71, 727-734. http://dx.doi.org/10.1590/S1519-69842011000400018

[5] Teixeira, E.W., Message, D., Meira, R.M.S.A. and Salatino, A. (2003) Indicadores da origem botânica da própolis: Importância e perspectivas. Boletim de Indústria Animal, 60, 83-106.

[6] Melo, A.A.M., Matsuda, A.H., Freitas, A.S., Barth, O.M. and Almeida-Muradian, L.B. (2014) Capacidade antioxidante da própolis. Pesquisa Agropecuária Tropical, 44, 341-348. http://dx.doi.org/10.1590/S1983-40632014000300004

[7] Kubiliene, L., Laugaliene, V., Pavilonis, A., Maruska, A., Majiene, D., Barcauskaite, K., Kubilius, R., Kasparaviciene, G. and Savickas, A. (2015) Alternative Preparation of Propolis Extracts: Comparison of Their Composition and Biological Activities. BMC Complementary and Alternative Medicine, 15, 156-163. http://dx.doi.org/10.1186/s12906-015-0677-5

[8] Vit, P., Huq, F., Barth, O., Campo, M., Pérez-Pérez, E., Tomás-Barberán, F. and Santos, E. (2015) Use of Propolis in Cancer Research. British Journal of Medicine and Medical Research, 8, 88-109. http://dx.doi.org/10.9734/BJMMR/2015/16216

[9] Wagh, V.D. (2013) Propolis: A Wonder Bees Product and Its Pharmacological Potentials. Advances in Pharmacological Sciences, 2013, Article ID: 308249. http://dx.doi.org/10.1155/2013/308249

[10] Siripatrawan, U., Vichayakitti, W. and Sanguandeekul, R. (2013) Antioxidant and Antimicrobial Properties of Thai Propolis Extracted Using Ethanol Aqueous Solution. International Journal of Food Science and Technology, 48, 22-27. http://dx.doi.org/10.1111/j.1365-2621.2012.03152.x

[11] Barth, O.M. (1998) Pollen Analysis of Brazilian Propolis. Grana, 37, 97-101. http://dx.doi.org/10.1080/00173139809362650

[12] Barth, O.M. and Luz, C.F.P. (2003) Palynological Analysis of Brazilian Geopropolis Sediments. Grana, 42, $121-127$. http://dx.doi.org/10.1080/00173130310012512

[13] Nogueira-Neto, P. (1953) A criação de abelhas indígenas sem ferrão. Editora Chácara e Quintais, São Paulo, 280 p.

[14] Silva, M.D. and Ramalho, M. (2014) Tree Species Used for Nesting by Stingless Bees (Hymenoptera: Apidae: Meliponini) in the Atlantic Rain Forest (Brazil): Availability or Selectivity. Sociobiology, 61, 415-422. http://dx.doi.org/10.13102/sociobiology.v61i4.415-422

[15] Freitas, A.S., Barth, O.M., Oliveira, E.S., Matsuda, A.H. and Almeida-Muradian, L.B. (2011) A Palynological Analysis of Brazilian Propolis Samples. Journal of ApiProduct and ApiMedical Science, 3, 67-74. http://dx.doi.org/10.3896/IBRA.4.03.2.01

[16] Freitas, A.S., Vit, P. and Barth, O.M. (2012) Pollen Profile of Geopropolis Samples Collected by Native Bees (Meliponini) in Some South American Countries. Sociobiology, 59, 1465-1482.

[17] Pereira, A.S., Seixas, F.R.M.S. and Aquino Neto, F.R. (2002) Própolis: 100 anos de pesquisa e suas perspectivas futuras. Química Nova, 25, 321-326. http://dx.doi.org/10.1590/S0100-40422002000200021

[18] Dutra, R.P., Abreu, B.V.B., Cunha, M.S., Batista, M.C.A., Torres, L.M.B., Nascimento, F.R.F., Ribeiro, M.N.S. and Guerra, R.N.M. (2014) Phenolic Acids, Hydrolyzable Tannins, and Antioxidant Activity of Geopropolis from the Stingless Bee Melipona fasciculata Smith. Journal of Agricultural Food and Chemistry, 62, 2549-2557. http://dx.doi.org/10.1021/jf404875v

[19] Alves, E. and Kubota, E.H. (2013) Conteúdo de fenólicos, flavonoides totais e atividade antioxidante de amostras de própolis comerciais. Revista de Ciências Farmacêuticas Básica e Aplicada, 34, 37-41.

[20] Veloso, H. (1962) Os grandes clímaces do Brasil—Considerações sobre os tipos vegetativos da região Sul. Memórias do Instituto Oswaldo Cruz, 60, 175-194. http://dx.doi.org/10.1590/s0074-02761962000200003

[21] Pinha, P.R.S. and Siminski, A. (2011) A região Sul. In: Coradin, L., Siminski, A. and Reis, A., Eds., Espécies Nativas da Flora Brasileira de Valor Econômico Atual ou Potencial: Plantas para o Futuro-Região Sul, MMA, Brasília, 65-88.

[22] Carmo, M.R.B., Andrade, A.L.P., Santos, G.A.S.D. and Assis, M.A. (2012) Análise estrutural em relictos de cerrado no Parque Estadual do Guartelá, Município de Tibagi, Estado do Paraná, Brasil. Ciência Florestal, 22, 505-517. http://dx.doi.org/10.5902/198050986618

[23] Negrelle, R.A.B. and Silva, S.C. (1992) Fitossociologia de um trecho de floresta com Araucária angustifolia (Bert.) O. Ktze. No município de Caçador Santa Catarina. Embrapa Florestas. Boletim de Pesquisa Florestal, No. 24/25, 37-54.

[24] Gasper, A.L., Sevegnani, L., Vibrans, A.C., Sobral, M., Uhlmann, A., Débora Vanessa Lingner, D.V., Rigon-Júnior, M.J., Marcio Verdi, M., Stival-Santos, A., Susana Dreveck, S. and Korte, A. (2013) Inventário florístico florestal de Santa Catarina: Espécies da Floresta Ombrófila Mista. Rodriguésia, 64, 201-210. http://dx.doi.org/10.1590/S2175-78602013000200001 
[25] Grings, M. and Brack, P. (2009) Árvores da vegetação nativa de Nova Petrópolis, Rio Grande do Sul. IHERINGIA, Série Botânica, 64, 5-22.

[26] Jacobi, U.S., Duarte, C.I., Gonçalves, R.S., Acunha, J.S. and Hefler, S.M. (2013) Florística dos ecossistemas do Campus Carreiros, Rio Grande, Rio Grande do Sul, Brasil. IHERINGIA, Série Botânica, 68, 73-89.

[27] Barth, O.M., Dutra, V.M.L. and Justo, R.L. (1999) Análise polínica de algumas amostras de própolis do Brasil Meridional. Ciência Rural, 29, 663-667. http://dx.doi.org/10.1590/S0103-84781999000400016

[28] Matos, V.R., Alencar, S.M. and Santos, F.A.R. (2014) Pollen Types and Levels of Total Phenolic Compounds in Própolis Produced by Apis mellifera L. (Apidae) in an Area of the Semiarid Region of Bahia, Brazil. Anais da Academia Brasileira de Ciências, 86, 407-418. http://dx.doi.org/10.1590/0001-376520142013-0109

[29] Ramalho, M. (2004) Stingless Bees and Mass Flowering Trees in the Canopy of Atlantic Forest: A Tight Relationship. Acta Botânica Brasílica, 18, 37-47. http://dx.doi.org/10.1590/S0102-33062004000100005

[30] Nascimento, A.S., Marchini, L.C., Carvalho, C.A.L., Araújo, D.F.D. and Silveira, T.A. (2015) Pollen Spectrum of Stingless Bees Honey (Hymenoptera: Apidae), Paraná State, Brazil. Journal of Entomology and Zoology Studies, 3, 290-296.

[31] Barth, O.M. (2006) Palynological Analysis of Geopropolis Samples Obtained from Six Species of Meliponinae in the Campus of the Universidade de Ribeirão Preto, USP, Brazil. APIACTA, 41, 71-85.

[32] Smith, N., Mori, S.A., Henderson, A., Stevenson, D.W. and Heald, S.V. (2004) Flowering Plants of the Neotropics. The New York Botanical Garden, Princeton and Oxford, 594 p.

[33] Bastos, E.M., Oliveira, V.D.C. and Soares, A.E.E. (2000) Microscopic Characterization of the Green Própolis, Produced in Minas Gerais State, Brazil. Honeybee Science, 21, 179-180. 